\title{
UNITED STATES' UNLAWFUL DRONE STRIKES AND DAMAGES CAUSED TO HUMANITY: A CASE STUDY OF PAKISTAN
}

\author{
Muhammad Imran \\ Faculty of Law, Universiti Kebangsaan Malaysia \\ E-mail:m.imran163@siswa.ukm.edu.my \\ Rohaida Nordin \\ Faculty of Law, Universiti Kebangsaan Malaysia \\ E-mail: rohaidanordin@ukm.edu.my \\ Mohd Munzil Muhamad \\ Faculty of Law, Universiti Kebangsaan Malaysia \\ E-mail: mohdmunzil@ukm.edu.my
}

\begin{abstract}
This paper contributes significantly through suggestions to overcome the problem created by the disastrous US drone strikes in Pakistan. This paper evaluates incidences of the United States' combat drone strikes in Pakistan and the damage caused to innocent people. It seeks to determine possible violations of international laws and the extent to which these strikes diminish the sovereignty of Pakistan. After the incident of 9/11, the use of combat drones in armed conflicts among states, non-state actors, disruptive groups and organisations has increased and expanded. Combat drones are controlled by operators who depend for their primary sources of information on cameras and sensors to determine their targets. Drone strikes lack identification processes causing many innocent people to be killed or injured. Drone strikes launched in non-conflict areas also increase the concerns about illegitimate interference in a state's territorial sovereignty and violations of international laws. It covers the following questions. What are the basic principles about the use of force? What kinds of damages are caused by US drone strikes in Pakistan that violate basic human rights principles? What are the concerns of international organisations about drone strikes in Pakistan? Summarily, it covers the United States unlawful drone strikes in Pakistan and damages caused to humanity. The
\end{abstract}


paper uses doctrinal qualitative analysis to situate the research within the ethical, legal and social parameters of the related statutes of international law. The research methodology adopted is evaluative, interpretive and analytical. The paper consists of 8 segments: (1) drones and the United States armed forces, (2) some basic international law principles about the use of force, (3) possible human rights violations, (4) US drone strikes diminish the sovereignty of Pakistan, (5) demands for transparency, (6) the damages caused to humanity by the drone strikes, (7) concerns of international organisations about illegitimate drone strikes causing extra judicial killings and (8) some recommendations to regulate the use of combat drones. It demonstrates that international law does not regulate the use of combat drones in armed conflict and no considerable effort has been made to bring the use of combat drones under the rule of law. Furthermore, US drone strikes in Pakistan's territory have been done without consensus, resulting in the violation of Pakistan's sovereignty and the killing of innocent people.

Keywords: Drone strikes, Human rights violations, Pakistan's territorial sovereignty, Rule of law.

Abstrak: Makalah ini menyumbang dengan ketara melalui cadangan untuk mengatasi masalah yang dicetuskan oleh serangan drone $A S$ di Pakistan. Ia juga menilai kejadian serangan drone AS di Pakistan dan kerosakan ke atas orang yang tidak bersalah. Ia bertujuan untuk menentukan kemungkinan pelanggaran undang-undang antarabangsa dan sejauh mana serangan ini mencabul kedaulatan Pakistan. Selepas insiden 9/11, penggunaan pesawat tempur dalam konflik bersenjata di antara negara, pelaku bukan negara, kumpulan dan organisasi telah meningkat dan berkembang. Pesawat tempur ini dikawal oleh pengendali yang bergantung pada kamera dan sensor sebagai sumber maklumat utama untuk menentukan sasaran mereka. Serangan drone mempunyai kelemahan dalam proses pengenalan yang mengakibatkan ramai orang tidak bersalah terbunuh atau cedera. Serangan drone yang dilancarkan di kawasan bukan konflik juga meningkatkan kebimbangan mengenai gangguan tidak sah dalam kedaulatan wilayah negara dan pencabulan undangundang antarabangsa. Makalah ini merangkumi soalan-soalan berikut: Apakah asas-asas mengenai penggunaan kekerasan? Apa jenis kerosakan yang disebabkan oleh serangan drone $A S$ di 
Pakistan yang melanggar prinsip asas hak asasi manusia? Apakah kebimbangan organisasi antarabangsa mengenai serangan di Pakistan? Ringkasnya, ia mengenai serangan drone AS yang menyalahi undang-undang di Pakistan dan kerosakan ke atas manusia. Makalah ini menggunakan analisis kualitatif dalam aspek etika, perundangan dan sosial yang berkaitan dengan undangundang antarabangsa. Metodologi penyelidikan yang dipakai adalah evaluatif, interpretatif dan analitikal. Makalah ini terbahagi kepada 8 bahagian: (1) drone dan angkatan bersenjata AS; (2) prinsip asas undang-undang antarabangsa tentang penggunaan kekerasan; (3) kemungkinan pelanggaran hak asasi manusia; (4) serangan drone AS dan pencabulan kedaulatan Pakistan; (5) tuntutan terhadap ketelusan; (6) kajian terhadap kerosakan yang disebabkan oleh serangan drone; (7) keprihatinan organisasi antarabangsa terhadap serangan drone tidak sah yang menyebabkan pembunuhan di luar kehakiman; dan (8) mengemukakan beberapa cadangan untuk mengawal penggunaan pesawat tempur. Makalah ini membuktikan bahawa undang-undang antarabangsa tidak dapat mengawal penggunaan pesawat tempur dalam konflik bersenjata dan tidak banyak usaha yang dibuat untuk membawa penggunaan pesawat tempur ini di bawah kedaulatan undang-undang. Tambahan pula, serangan drone AS di wilayah Pakistan telah dilakukan tanpa persetujuan, mengakibatkan pencabulan kedaulatan Pakistan dan pembunuhan orang yang tidak bersalah.

Kata Kunci: Serangan, Pelanggaran hak asasi manusia, Kedaulatan wilayah Pakistan, Peraturan undang-undang.

\section{INTRODUCTION}

The complicated connection between war and civil liberties is a growing challenge in an environment of increased armed conflict. The advancement in technology has transformed the nature of modern war with the use of unmanned combat aerial vehicles, i.e. drones. Drones are one of the most used, preferred and effective armed innovations of present times. ${ }^{1}$ In armed conflict, drones can accurately target enemies and reduce dangers for armed forces by

A. Funk, 'Drones in contemporary warfare: The implications for human rights', LSE Human Rights Blog, 2016. 
keeping them physically distanced from the battlefield. Drones are commonly used in armed conflict and reduce geographic constraints for observation and surveillance. However, targeting with drones is only lawful in the presence of real armed conflict or with the consent of the "host state". ${ }^{2}$ The accuracy and success of a drone strike depend on the operator and the intelligence. Sometimes intelligence failures and poor weather conditions result in the deaths of innocents. Such an outcome violates human rights. As revealed in the aftermath of the United States drone strategy, drones endanger human rights, especially the right to life which is a violation of article 2 of the International Covenant on Civil and Political Rights (ICCPR). Drones should only be used when meeting the international human rights obligations especially under the International Human Rights Law (IHRL) and International Humanitarian Law (IHL). ${ }^{3}$

This paper has eight parts. First, it demonstrates the participation of CIA officials in conducting drones strikes. Second, it explains jus ad bellum and jus in Bello about the use of force. The third part evaluates the possible human rights violations. Fourth, it describes that US combat drone attacks are violating Pakistan's territorial sovereignty and integrity. Fifth, it demonstrates the need for transparency. The sixth part gives a brief overview of the destruction caused by US drone strikes in Pakistan. The seventh part expresses the worries of international organisations about the unlawful use of combat drones causing extra judicial killings. The final part gives some suggestions to regulate the use of combat drones.

\section{DRONES AND THE UNITED STATES OF AMERICA (USA) ARMED FORCES}

After the attacks on September 11, 2001, conflicts among states, non-state actors and disruptive groups have led to the increased use of combat drones. ${ }^{4}$ Its use increased further during the Presidency of

2 T. M. McDonnell, 'Sow What You Reap: Using Predator and Reaper Drones to Carry Out Assassinations or Targeted Killings of Suspected Islamic Terrorists', Geo. Wash. International Law Review, vol. 44, 2012, p.291.

3 A. Funk, 'Drones in contemporary warfare: The implications for human rights', LSE Human Rights Blog, 2016.

4 J. Arasli, States vs. Non-State Actors: Asymmetric Conflict of the 21st Century and Challenges to Military Transformation, INEGMA Special Report No. 13, 2011. 
Barack Hussain Obama. Since then, it has been a consistent armed strategy of the USA against Al-Qaeda and the Taliban in Afghanistan and Pakistan. ${ }^{5}$ Initially, Predator drones were commonly used to conduct airstrikes. However, later on with the advancement of drones, Reaper and Avenger drones are being used for conducting airstrikes which are more advanced and can fly with heavy weapons. ${ }^{6}$

The advancement in drone technology has desensitised and brutalised war further through the use of indiscriminate force. American drone operators could be in Nevada or Virginia and receive instructions from US forces in Afghanistan. ${ }^{7}$ This physical distance creates emotional distance and enables the drone operators to use disastrous force more comfortably than the soldiers in the battlefield without caring for the consequences of their drone strikes which may result in an enormous number of civilian deaths. Moreover, drones are being used like computer games, except that the targets are living persons. A young armed officer expressed: "It's like a video game, the ability to kill. It's like freaking cool". ${ }^{8}$

The USA's drone operations in striking identified persons in "personality strikes" and striking "unknown" persons in "signature strikes" have obscure parameters and are a threat to civilian lives. ${ }^{9}$ According to CIA officials, while conducting personality strikes, all persons involved in the process should be highly confident that the targeted person is present. In signature strikes, CIA officials target the persons without knowing their complete identity. Instead, CIA officials target any person for pre-identified behaviour associated

5 A. Dworkin, Drones and targeted killing: Defining a European position, European Council on Foreign Relations (ECFR), 35 Old Queen Street, London, SW1H9JA, United Kingdom, 2013.

6 A. Funk, 'Drones in contemporary warfare: The implications for human rights', LSE Human Rights Blog, 2016.

7 R. Williams, 'Current Unmanned Aircraft State Law Landscape', In National Conference of State Legislatures, 2014.

8 D. Kilcullen, 'Predator Drones - two words for you - no joke (they provoke counter attacks seen as legitimate defense)', 18 July 2011, [web blog], https:// supportdanielboyd.wordpress.com/predator-drones-two-words-for-you-nojoke/, (accessed 20 November 2017).

9 S. Holewinski, 'The Constitutional and Counterterrorism Implications of Targeted Killing', 30 April 2013, https://civiliansinconflict.org, (accessed 17 November 2017). 
with terrorist activity. ${ }^{10}$ CIA officials reveal less information about signature strike procedures than personality strikes. Signature strikes are controversial as they can cause an enormous number of deaths based merely on pre-identified behaviour. Signature strikes consider the types of people, men having weapons or in terrorist compounds, persons in a convoy of automobiles that have characteristics similar to Al-Qaeda or Taliban leaders. ${ }^{11}$

The secret drone operations conducted by the USA in Pakistan consist of a large number of signature strikes. ${ }^{12}$ Most drone strikes occur in areas generally unapproachable to autonomous external actors. Whether it is a personality strike or a signature strike, the lack of US armed personnel in the field to investigate means there are few pathways to verify evidence that the strike has gone well and evaded civilians. Camera surveillance is no substitute for eyewitnesses nor can it explore wreckages for forensic evidence. Further, civilians have no way of informing officials of what occurred to them and their families as there is no US centre or court to claim compensation. ${ }^{13}$

An incident that occurred in Shiga, Pakistan, reveals the flaws of the CIA's current signature strikes. The CIA carried out a signature strike on a group on 17 March 2011 assuming that some of its members were linked to Al-Qaeda and all "acted in a manner consistent with Al-Qaeda linked militants." The CIA had claimed to kill 20 terrorists. However, according to locals, CIA's official missile struck a Jirga, which was held to resolve a mining dispute. It killed four Taliban terrorists and 38 civilians including tribal police. A farmer named Gul Ahmed said that terrorists were present there because they controlled the area and any decision made would require their approval. ${ }^{14}$

10 J. Tandler, 'Known and Unknowns: President Obama's Lethal Drone Doctrine', Fondation pour la Recherche Strategique note, vol. 7, no.13, 2013, p. 1-5.

11 S. Ali, \& C. Abbott, 'US Drone Strikes in Pakistan: Ineffective and illegitimate', 24 October 2013, https://sustainablesecurity.org, (accessed 15 November 2017).

12 J. Tandler, 'Known and Unknowns: President Obama's Lethal Drone Doctrine', Fondation pour la Recherche Strategique note, vol. 7, no.13, 2013, p. 1-5.

13 S. Holewinski, 'The Constitutional and Counterterrorism Implications of Targeted Killing', 30 April 2013, https://civiliansinconflict.org, (accessed 17 November 2017).

14 N. Shah., R. Chopra., J. Morna., C. Grut., E. Howie., D. Mule., \& M. Abbott, The Civilian Impact of Drones: Unexamined Costs, Unanswered Questions, 
Pakistan's Army Chief, General Ashfaq Parvez Kayani, issued a statement stating that tribal elders are "carelessly and callously targeted with complete disregard to human life." These contradictory statements indicate the challenges of identifying the individuals who are killed by drone attacks and raise questions to the USA administration for its ingenuity in counting deaths. ${ }^{15}$

In 2002, Daraz Khan and his two companions were collecting scrap metal on top of a mountain near Southern Afghanistan. Flying above was a drone which received information that the men in robes who were in a suspected Al-Qaeda area resembled Osama Bin Laden. The drone operator had a firm belief that the strike was right because Khan had conspicuous similarities to Osama Bin Laden. However, Khan's physical examination revealed that he was almost half a foot shorter than Osama Bin Laden. This drone attack resulted in the deaths of three innocent civilians which could have been avoided with precise information before approving the attack. ${ }^{16}$

Amnesty International, the United Nations and the Bureau of Investigative Journalism have researched the incidents of civilian damage in Pakistan and gathered media reports of attacks to estimate the figures of civilian killings. President Barack Obama's administration claimed that USA drones killed 64 to 116 innocent civilians, but according to research by the Bureau of Investigative Journalism, at least 380 to 801 innocent civilians were killed. Admittedly, access is also a challenge for those organisations. Although their estimations show a discrepancy about the total numbers of civilian deaths, these organisations always indicate significantly higher civilian deaths than those presented by the US administration. ${ }^{17}$

Center for Civilians in Conflict, Columbia Law School Human Rights Clinic, 20, 2012.

15 N. Shah., R. Chopra., J. Morna., C. Grut., E. Howie., D. Mule., \& M. Abbott, The Civilian Impact of Drones: Unexamined Costs, Unanswered Questions, Center for Civilians in Conflict, Columbia Law School Human Rights Clinic, 20, 2012.

16 C. W. Staff, 'Drone Strikes Kill, Maim, and Traumatize Too Many Civilians, US Study Says', 25 September 2012, edition.cnn.com/2012/09/25/world/asia/ pakistan-us-drone-strikes, (accessed 19 November 2017).

17 S. Holewinski, 'The Constitutional and Counterterrorism Implications of Targeted Killing', 30 April 2013, https://civiliansinconflict.org, (accessed 17 November 2017). 


\section{INTERNATIONAL LAWS REGARDING USE OF FORCE: JUS AD BELLUM AND JUS IN BELLO}

\section{Jus Ad Bellum}

Maintaining international peace and security is a principal objective of the United Nations under article 1(1) of its charter. To accomplish this goal, article 24 encompasses the prohibition of the use of force among UN member states. Articles 39 and 51 of the UN charter contain sanctions which are imposed against any state that violates the provisions of the UN charter regarding the use of force. ${ }^{18}$

According to article 1(1) of the UN charter, its objective is, "To maintain international peace and security, and to that end: to take effective collective measures for the prevention and removal of (a) threats to the peace, and for the (b) suppression of acts of aggression or (c) other breaches of the peace, and to bring about by peaceful means.... adjustment or settlement of international disputes or situations which might lead to a breach of the peace."19

For sustaining international peace and security and to prevent wars among member states, article 2(3) of the UN charter sets responsibility on member states to resolve their issues peaceably. It states, "All members shall settle their international disputes by peaceful means in such a manner that international peace and security, and justice, are not endangered." ${ }^{20}$ Article 2(4) forbids member states to use force against any other member state. It states, "All members shall refrain in their international relations from the threat or use of force against the territorial integrity or political independence of any state, or in any other manner inconsistent with the Purposes of the United Nations." ${ }^{21}$

A collective sanction system secures this prohibition. Articles 39 to 51 contain sanctions which are imposed against any offending member state that violates these international peacekeeping provisions. Article 39 of the UN charter states, "The Security Council

\footnotetext{
United Nations Charter Article 39 to 51.

United Nations Charter Article 1.

United Nations Charter Article 2(3).

United Nations Charter Article 2(4).
} 
shall determine the existence of any threat to the peace, breach of the peace, or act of aggression and shall make recommendations, or decide what measures shall be taken in accordance with articles 41 and 42 , to maintain or restore international peace and security." 22

The Security Council under article 41 of the UN charter is authorised to impose business, industrial and weapons restrictions. Article 41 of the United Nations charter states, "The Security Council may decide what measures not involving the use of armed force are to be employed to give effect to its decisions, and it may call upon the members of the United Nations to apply such measures. These may include complete or partial interruption of economic relations and of rail, sea, air, postal, telegraph, radio and other means of communication, and the severance of diplomatic relation. ${ }^{n 3}$

The Security Council is allowed to use the force required under article 42 of the UN charter to maintain international peace. The Security Council allows member states to use force against offending states to restore international peace and security as it does not have its own armed force. Article 42 of the UN charter states, "Should the Security Council consider that measures provided for in Article 41 would be inadequate or have proved to be inadequate, it may take such action by air, sea, or land forces as may be necessary to maintain or restore international peace and security. Such action may include demonstrations, blockades and other operations by air, sea, or land forces of Members of the United Nations." ${ }^{24}$

In the case of armed attacks against any member state, article 51 of the UN charter allows the member state to use force in its defence: "Nothing in the present Charter shall impair the inherent right of individuals or collective self-defence if an armed attack occurs against a Member of the United Nations, until the Security Council has taken measures necessary to maintain international peace and security. Measures taken by Members in the exercise of this right of self-defence shall be immediately reported to the Security Council and shall not in any way affect the authority and responsibility of the Security Council under the present Charter to take at any time

\footnotetext{
$22 \quad$ United Nations Charter Article 39.

23 United Nations Charter Article 41.

24 United Nations Charter Article 42.
} 
such action as it deems necessary in order to maintain or restore international peace and security." 25

The International Court of Justice (ICJ) permits member states to use force against the offending state in self-defense following the set doctrines of necessity and proportionality. ${ }^{26}$

\section{International law for the use of drones}

The US defends its attack on Afghanistan on the basis of the same provision of the UN charter about self-defence. It describes the events of 9/11 as armed attacks discounting the fact that until today, the perpetrators of the 9/11 attacks are still unknown while also discounting the doctrines of necessity and proportionality.

In 2002, Hamid Karzai after ending the Taliban rule came into power in Afghanistan and requested the already present international military forces in the state to combat the rebellious sets. ${ }^{27}$ Therefore, the US's legitimate use of force was restricted to the boundaries of Afghanistan. Since then, the US has started using combat drones in the tribal areas of Pakistan to target several terrorist groups with and without the permission of Pakistan. It has also used drone missiles in non-conflict areas without the consent of Pakistan. ${ }^{28}$

Although it is intimated that several terrorist groups regularly cross the boundaries of Afghanistan and enter into Pakistan, this does not authorise the US to use force or perform drone attacks in Pakistani territory without its consent. Similarly, that a terrorist group organises or performs a terrorist action in a state does not allow using force under the right of self-defence because such activities are carried out by non-state actors and states are seldom liable for such actions. ${ }^{29}$

\footnotetext{
25 United Nations Charter Article 51.

26 J. Moussa, 'Can Jus ad Bellum override Jus in Bello? Reaffirming the Separation of the Two Bodies of Law', International Review of the Red Cross, vol. 90 no.872, 2008, p.963-990.

27 W. A. Qureshi, 'The legality and conduct of drone attacks', Notre Dame Journal International Comparative Law, vol.7, no.2, 2017, p. 91.

28 B. J. Strawser, et al., Opposing perspectives on the drone debate, 1st ed, Palgrave Macmillan in the United States, 2014, p. 177.

29 United Nations Charter Article 51.
} 
Apart from these clear rules, the US claims that the 9/11 attacks signify the use of force and as a result, it can use any possible action to fight against Al-Qaeda anywhere in the world. President George W. Bush defends the use of force by labelling it the "global war on terror" while President Barack Hussein Obama describes it as armed conflict with Al-Qaeda and other related groups to defend its use of force under the pretence of self-defence. The Obama government adopts the "pre-emptive self-defence" model to end "future attacks". This approach conflicts with the set rules of customary international law. ${ }^{30}$

According to the International Law Association (ILA), armed conflict is described by setting basic parameters for the use of force in which an armed conflict must have an organised party battling other parties. The isolated attacks of terrorist groups do not constitute an armed conflict and do not fall under the standards mentioned above. ${ }^{31}$ Moreover, the US has attempted to defend its drone strikes based on the doctrine of Hot Pursuit. However, this law is applicable only on the seas and not on the land. ${ }^{32}$

\section{The importance of the consent of the host state}

The topic of consent is essential in evaluating the legitimacy of the use of drone missiles for two purposes. Primarily, a state cannot use force without the presence of real armed conflict even in its territory. Secondly, if a real armed conflict exists, then the drone strikes must meet the doctrines of necessity and proportionality. ${ }^{33}$

There are various concerns regarding the drone strikes working without the consent of the affected states. Drone attacks without the consent of the affected states contravene US policies and the sovereignty of the "host state". However, the US rejects claims

30 W. A. Qureshi, 'The legality and conduct of drone attacks', Notre Dame Journal International Comparative Law, vol.7, no.2, 2017, p. 91.

31 J. Summers, Kosovo: A precedent?: The declaration of independence, the advisory opinion and implications for statehood, self-determination and minority rights, Leiden Boston, Brill, 2011.

32 Convention on the High Seas Article. 23, 29 April 1958, 13 U.S.T. 2312, 450 U.N.T.S. 11.

33 D. Akerson, 'Applying Jus in Bello proportionally to drone warfare', Or. Rev. International Law., vol.16, 2014, p.173. 
that the "host states" have not given the authority to conduct drone strikes in their territories. ${ }^{34}$

A book titled Confront and Conceal by David Sanger in 2008 claims that Prime Minister Yusaf Raza Gillani said to Anne Patterson, the US Ambassador that, "I do not care if you conduct the drone attacks, as long as you get the right people". ${ }^{35}$ The US also claims that Pakistan has authorised it to conduct combat drone strikes using Pakistani air bases and that it assists US armed forces by providing information for finding the targets in the Federal Administrative Tribal Areas (FATA). ${ }^{36}$

In 2012, the New York Times named the persons employed by Pakistan's military intelligence to assist US officials to conduct drone strikes. However, these officials opposed Pakistan's official stand that opposes the drone attacks. ${ }^{37}$ Some reports claim that the US did not obtain official authorisation from Pakistan to conduct drone strikes in its territory, but rather it got "tacit consent" by Pakistan not resisting the strikes by effectively allowing them to proceed. ${ }^{38}$

These claims are controversial because Pakistan's official stance contradicts such statements. ${ }^{39}$ According to Harold Koh, the absence of official authority is an act of war against the sovereignty

34 B. Tau, 'Brennan: Drones 'necessary', POLITICO', POLITICO, 30 April 2012, https://www.politico.com/story/2012/04/brennan-drones-necessary-notvengeance-075751, (accessed 4 December 2017).

35 D. E. Sanger, 'Obama order sped up wave of cyber attacks against Iran', The New York Times, 1 June 2012, http:/www.nytimes.com/2012/06/01/world/ middleeast/obama-ordered-wave-of-cyberattacks-against-iran.html, (accessed 5 December 2017).

36 Z. Ahmed, 'Strengthening standards for consent: The case of U.S. drone strikes in Pakistan', Michigan State International Law Review, vol.23 no.2, 2015, p. 491-500.

37 D. Walsh, 'Drone war spurs militants to deadly reprisals', New York Times, 29December 2012, http://www.nytimes.com/2012/12/30/world/ asia/drone-war-in-pakistan-spurs-militants-to-deadly-reprisals.html, (accessed 3 December 2017).

38 D. A. Mahapatra, Conflict and peace in Eurasia, London and New York, Routledge, 2012.

39 A. Entous, S. Gorman \& E. Perez, 'US unease over drone strikes: Obama administration charts delicate legal path defending controversial weapons', The Wall Street Journal, 2012, p. 26. 
of Pakistan. ${ }^{40}$ The Bureau of Investigation Journalism also claims that Pakistan has not authorised or granted consent to conduct drone strikes on its land and opposes "tacit consent". ${ }^{41}$

In 2012, Pakistan's parliament collectively approved the immediate closure of the United States drone struck in Pakistan. ${ }^{42}$

\section{Jus in Bello}

The presence of an armed conflict decides the applicability of IHL and IHRL. Both laws are applicable only in armed conflict and serve to determine the legality of killing. ${ }^{43}$ There will be an actual armed conflict if the following two conditions of these laws are met. ${ }^{44}$

Firstly, ferocity should be of an intense nature, and armed conflict is separated from in-house disruptions or isolated and intermittent acts of violence..$^{45}$ Secondly, the belligerent should be appropriately organised to be categorised as participants in an armed conflict. ${ }^{46} \mathrm{~A}$ non-state actor that is appropriately organised and having a chain of command and the capability to perform armed operations can be deemed a "party". ${ }^{47}$

40 F. Sperotto, 'The future of the American fight against terrorism', Rivista di Studi Politici Internazionali, 2014, p.221-230.

41 C. Woods, 'Pakistan 'categorically rejects' claim that it tacitly allows U.S. drone strikes', the Bureau of Investigative Journalism, 28 September 2012, [website],https://www.thebureauinvestigates.com/stories/2012-09-28/ pakistan-categorically-rejects-claim-that-it-tacitly-allows-us-drone-strikes, (accessed 30 November 2017).

42 U.N., 'Pakistan presses on its demand for end to illegal drone strikes', THE NEWS, 2 July 2016, https://www.thenews.com.pk/latest/132367-Pakistanpresses-demand-end-illegal-drone-strikes, (accessed 2 December 2017).

${ }^{43} \mathrm{~J}$. B. Hosang, 'The effects of paradigm shifts on the rules on the use of force in military operations, Netherlands International Law Review, vol.64, no.3, 2017, p. 353-373.

44 IT-03-66-T, Prosecutor v. Limaj, 84, 2005, ICTY 30 November 2005.

45 T. Kelisiana, "Targeting the "terrorist enemy": The boundaries of an armed conflict against transnational terrorists', Australian International Law Journal, vol.16, 2009, p. 161-166.) \& See Case No. IT-04-82-T, Prosecutor v. Boskoski, Judgment, 2008, 175, ICTY 10 July 2008.

46 L. Noam, 'Extraterritorial use of force against non-state actors', Military Law and the Law of War Review, vol.49, 2010, p. 173.

47 IT-04-82-T, Prosecutor v. Boskoski, Judgment, 2008, 199-203, ICTY 10 July 2008, Detailing five categories of factors. 
The evaluation of war is complicated by the 'global war on terror' announced by the Bush administration and the 'translational armed conflict' against Al-Qaeda claimed by the Obama administration. ${ }^{48}$

In the absence of "actual armed conflict" in Pakistan and the absence of valid consent, the US is committing war crimes by violating the sovereignty of Pakistan under international law. ${ }^{49}$

\section{The principles of $I H L$}

In an armed conflict, the deliberate use of force is lawful if it fulfils the principles of "International Humanitarian Law" sometimes referred to as "Jus in Bello". The doctrine of "distinction" is imperative and identifies persons involved in armed attacks as lawful targets of military force while the law protects persons who are not involved in armed attacks. ${ }^{50}$

This rule of "distinction" is hard to use in disputes comprising nonstate actors because participants of military groups do not proceed to extricate themselves from those who are not involved in conflicts. Moreover, the related treaties do not explain the terms of "civilian" and "armed forces". ${ }^{1}$

\section{ARMED DRONES AND VIOLATIONS OF HUMAN RIGHTS}

Extensive use of armed drones means that more states and possibly non-state actors may also try to use this unmanned equipment. This situation is alarming. The strikes with armed drones have resulted in a significant number of civilian deaths in addition to the extrajudicial killings of the suspected terrorists. ${ }^{52}$ Drone missiles often kill

48 W. Benjamin,_'Jeh Johnson, 'National security law, lawyers and lawyering in the Obama Administration', Speech at Yale Law School, 22 February 2012, [website], http://www.lawfareblog.com/2012/02/jeh-johnson-speech-at-yalelawschool, (accessed 28 November 2017).

49 W. A. Qureshi, 'The legality and conduct of drone attacks', Notre Dame Journal of International \& Comparative Law, vol.7, no.2, 2017, p.5.

50 The Additional Protocols I of 8 June 1977 (API) Art. 51(2).

51 J. K. Kleffner, 'From 'belligerents' to 'fighters' and civilians directly participating in hostilities-on the principle of distinction in non-international armed conflicts one hundred years after the second Hague Peace Conference', Netherlands International Law Review, vol.54, no.2, 2007, p.315-336.

52 K. Anderson, 'Rise of the drones: Unmanned systems and the future of war', 
individuals based on vague identification mechanisms and without a fair public court hearing which is a violation of Article 14 of the ICCPR. ${ }^{53}$ While discussing the national security and fight against terrorists, states refuse to take responsibility for these extrajudicial killings, which consequently generates an environment of freedom for such killings. This has raised questions about violations of human rights and international humanitarian law. ${ }^{54}$ The US's drone strikes in Pakistan have violated the international law standards. ${ }^{55}$ According to article 6(1) of the ICCPR, "Every human being has the inherent right to life. No one shall be arbitrarily deprived of his life." This right is a resolute standard of international law and can never be suspended in wars or conflicts. An international treaty binds both the US and Pakistan being state parties of ICCPR to comply with this law. ${ }^{56}$

The use of armed drones also creates an environment of fear and anxiety in areas of Pakistan targeted by the haphazard and disparate drone attacks. ${ }^{57}$ Drones have gravely destroyed human rights such as the right of peaceful gathering (violation of article 21 of ICCPR), freedom of religion, the right of education and support to sufferers of drone attacks which is another violation of article 18 of ICCPR. ${ }^{58}$

American University Washington College of Law, 2010.

53 International Covenant on Civil and Political Rights, Adopted by the General Assembly of the United Nations on 19 December 1966, Article 14.

54 O. Bowcott, 'Drone strikes threaten 50 years of international law, says UN rapporteur',The Guardian,21 June2012, http://www.agriculturedefensecoalition. org/sites/default/files/file/drones_517/517X_1_2012_U.S._Drone Strikes_Threaten_50_Years_of_International_Law_Guardian.co.uk_ June_21_2012pdf.pdf, (accessed 17 November 2017).

55 C. Jenks, 'Law from above: Unmanned aerial systems, use of force, and the law of armed conflict', $N D L$, Rev. 85, 2009, p. 649.

56 M. Sterio, 'The United States' use of drones in the War on Terror: The (IL) legality of targeted killings under international law', Case W. Res. J. Int'l L., vol. 45, 2012, p. 197.

57 M. Akbar, Drone attacks and suicide bombings: Reflections on Pakistan's victims, In International Perspectives on Terrorist Victimisation, London, Palgrave Macmillan, 2015, pp. 201-224. Available from: E-Book Library, (accessed 23 November 2017).

58 J. Becker, \& S. Shane, 'Secret 'kill list' proves a test of Obama's principles and will', New York Times, 29 May 2012, www.nytimes.com/2012/05/29/world/ obamas-leadership-in-war-on-al-qaeda.html, (accessed 15 November 2017). 


\section{US DRONE ATTACKS AND SOVEREIGNTY OF PAKISTAN}

Drone strikes started in Pakistan under President Bush and continued under President Obama's government despite the opposition from Pakistan's administration. In Pakistan, President Obama endorsed "personality strikes' aimed at killing high-profile militants and "signature strikes" to destroy training camps and dubious compounds in the zones controlled by terrorists ${ }^{59}$. Signature strikes are still in practice despite growing opposition from Pakistan as it violates its airspace and endangers its sovereignty. Pakistani citizens have become more angered than ever over continued US drone operations in the country. ${ }^{60}$ Allegedly, these covert signature strikes have killed 416-959 innocent civilians ${ }^{61}$.

Ben Emmerson, the UN special rapporteur on human rights and counter-terrorism and head of a UN team investigating losses from the US drone attacks in Pakistan, announced after a secret research tour that the US drone strikes violate Pakistan's sovereignty. Emmerson met with Pakistani officials and announced that "the position of the government of Pakistan is quite clear, it does not consent to the use of drones by the United States on its territory, and it considers this to be a violation of Pakistan's sovereignty and territorial integrity. He also said that the drone operation "involves

the use of force on the territory of another state without its consent and is, therefore, a violation of Pakistan's sovereignty." 62

Pakistan alleges that the US drone strikes are "radicalising" a new "generation" of terrorists while the country itself was able to fight against extremism in its territory. Emmerson during his visit met with different Pakistani officials including tribal leaders from North

59 J. Becker, \& S. Shane, 'Secret 'kill list' proves a test of Obama's principles and will', New York Times, 29 May 2012, www.nytimes.com/2012/05/29/world/ obamas-leadership-in-war-on-al-qaeda.html, (accessed 15 November 2017).

60 RT. America, 'Drones Kill First, Ask Later',7 November 2011, https://www. rt.com, (accessed 12 November 2017).

61 The Bureau of Investigative Journalism, [website], https://www. thebureauinvestigates.com, (accessed 22 November 2017).

62 AP, 'U.N.: Drone strikes violate Pakistan's sovereignty', USA Today, 15 March 2013, https://www.usatoday.com, (accessed 24 November 2017). 
Waziristan (the area most targeted by U.S. drones). ${ }^{63} \mathrm{He}$ claims that "the tribal leaders said innocent tribesmen were often mistakenly targeted by drones because they were indistinguishable from the Taliban militants" as tribesmen and terrorist groups wear similar traditional tribal clothes and usually carry guns along with them at all times. ${ }^{64}$

Therefore, the US's current operational drone policy in Pakistan, which is not an armed conflict area, is highly controversial and violates IHRL including the right to life and the right to due process ${ }^{65}$ Thus, US drone strikes in Pakistan raise fears about violation of Pakistani sovereignty and human rights. ${ }^{66}$ It is a violation of article 2(4) of the UN charter that prohibits a member state to use force against any other member state. Moreover, the failure to make countries answerable for the human rights violations under IHRL is another violation in itself. So, there must be legal accountability by the US for using indiscriminate drone force against innocent civilians in Pakistan. ${ }^{67}$

\section{NEED FOR TRANSPARENCY}

The absence of transparency is a major concern within the current use of drone attacks as duly recognised in the report of the Women's International League for Peace and Freedom (WILPF). It claims that "based on available information, it is difficult to investigate how the current use of drones is in compliance with international law (since)

63 B. Wittes, 'U.N. Special Rapporteur Statement on Pakistan and Drone Strikes', 1 September 2013, [web blog], http://www.lawfareblog.com, (accessed 27 November 2017).

64 AP, 'U.N.: drone strikes violate Pakistan's sovereignty', USA Today, 15 March 2013, https://www.usatoday.com, (accessed 24 November 2017).

65 M. Sterio, 'The United States' use of drones in the war on terror: the (IL) legality of targeted killings under international law', Case W. Res. J. Int'l L., vol. 45, 2012, p. 197.

66 A. C. Orr, 'Unmanned, unprecedented, and unresolved: The status of American drone strikes in Pakistan under international law, Cornell Int'l LJ, vol.44, 2011, p. 729.

67 Amnesty International, USA must be held to account for drone killings in Pakistan, [website], 2013, https://www.amnesty.org, (accessed 15 November 2017). 
there is an awful lack of transparency regarding the standards used to identify those who constitute a legal target as well as the number of civilians killed." 68

The legitimacy of any drone attack is difficult to judge due to the lack of transparency. Despite enormous civilian killings, the states using armed drones do not recognise that their strikes have caused such killings. In the absence of transparency, there is no way for the general public to judge the legality or illegality of civilians' killings. The absence of transparency obscures accountability and facilitates abuses of international laws. ${ }^{69}$ Therefore, the US should announce the results of each strike publicly. This would make the accountability of the CIA officials involved in civilian killings possible. ${ }^{70}$

Some US State Department officials have criticised that the criteria exercised by the CIA officials for detecting a terrorist "signature" are extremely non-judgemental. One senior CIA official alleged that it is a joke that CIA officials consider tribesmen doing "jumping jacks" at a terrorist training camp. ${ }^{71}$

The Bureau of Investigative Journalism has performed field research by taking field work of other organisations including the Associated

Press and Amnesty International and spent almost three years collecting and analysing media reports to derive an opinion about "what the US is doing with its drones in Pakistan." This research calls for transparency of an alleged covert drone war and the verification of the US government's claims on their drone attacks. It reveals that the CIA director John Brennan's statement that "U.S. drones had not killed a civilian from August 2010 till the end of June 2011" was

68 WILPF, 'Armed drones killing human rights?', 29 September 2014, http:// wilpf.org, (accessed 26 November 2017).

69 WILPF, 'Armed drones killing human rights?', 29 September 2014, http:// wilpf.org, (accessed 26 November 2017).

70 Amnesty International, USA must be held to account for drone killings in Pakistan, [website], 2013, https://www.amnesty.org, (accessed 15 November 2017).

71 J. Becker, \& S. Shane, 'Secret 'kill list' proves a test of Obama's principles and will', New York Times, 29 May 2012, www.nytimes.com/2012/05/29/world/ obamas-leadership-in-war-on-al-qaeda.html, (accessed 15 November 2017). 
untrue. The research shows at least 73 innocent civilians, including 12 children were reportedly killed during that period. Despite the isolation of tribal areas of Pakistan, news emerges because of the courage of Pakistan's journalists. ${ }^{72}$

Furthermore, Amnesty International's appeal for transparency emphasises the troubles faced by the families of drone victims to get compensation. The Amnesty International's report, Will I be next? US drone strikes in Pakistan argues that "the lack of disclosure about drone strikes means that victims are able to access neither justice nor compensation." The report also states, "Secrecy surrounding the drones program gives the USA's administration a licence to kill beyond the reach of the courts or basic standards of international law. What hope for redress can there be for victims of the drone attacks and their families when the USA won't even acknowledge its responsibility for particular strikes?'”3

\section{DAMAGE OF US DRONE STRIKES IN PAKISTAN}

There may be systematic defects in the intelligence upon which strike decisions are based. These defects may include restrictions in drone video observation, signals interruption, cultural knowledge and human intelligence presented by local informers and collaborating governments. While making decisions about strikes, the operators

have to rely on the information collected from the drone's cameras and sensors. These are the sources of primary information while minimal information comes from the field. ${ }^{74} \mathrm{~A}$ drone's efficiency is also be affected by environmental conditions and can only assess one particular place at a time. ${ }^{75}$ Moreover, targets are often

72 J. Serle, 'The lack of transparency in drone attacks', 16 October 2014, http:// www.rawa.org, (accessed 11 November 2017).

73 Amnesty International, "Will I be next?" US drone strikes in Pakistan, [website], 2013,https://www.amnestyusa.org, (accessed 15 November 2017).

74 M. E. O'Connell, 'Unlawful killing with combat drones: A case study of Pakistan, 2004-2009', Notre Dame Law School, 2010.

75 S. J. Kim, G. J. Lim, \& J. Cho, 'Drone relay stations for supporting wireless 
surrounded by innocent people who become victims having no part in the conflict and are simply in the wrong place at the wrong time. ${ }^{76}$

Due to these defects or shortcomings, about $32 \%$ innocent civilians have been killed in the US drone strikes in Pakistan. From June 2004 to February 2015, the CIA had conducted 413 drone strikes in Pakistan. According to Bureau of Investigative Journalism (BIJ), the strikes have killed 2,438-3,942 people; 416-959 of whom were civilians and 168-204 were children. ${ }^{77}$ Apart from the vast number of civilians killed, in reality, one civilian death or injury changes the life of an entire family. In Pakistan, families are often big, and their welfare is interconnected. Therefore, the death of one member can create long-life instability, especially if an income producer is killed. $^{78}$

Table 1. CIA and US Military Drone Strikes, Minimum People Killed Including Terrorists and Minimum Civilians Killed (Innocent Civilians) in Pakistan, 2004 till Present

\begin{tabular}{cccc}
\hline Year & $\begin{array}{c}\text { US Drone } \\
\text { Strikes }\end{array}$ & $\begin{array}{c}\text { Minimum } \\
\text { people killed }\end{array}$ & $\begin{array}{c}\text { Minimum } \\
\text { civilians killed }\end{array}$ \\
\hline 2004 & 1 & 6 & 2 \\
2005 & 3 & 16 & 5 \\
2006 & 2 & 94 & 90 \\
2007 & 5 & 36 & 11 \\
2008 & 38 & 252 & 59 \\
\hline
\end{tabular}

communication in military operations', In International Conference on Applied Human Factors and Ergonomics, Springer, Cham. Vol. 595, 2017, pp. 123130.

76 M. Benjamin, Drone warfare: Killing by remote control, New York and London, Verso Books, 2013.

77 M. I. Ahmad, 'The magical realism of body counts: How media credulity and flawed statistics sustain a controversial policy', Journalism, vol.17, no.1, 2016, p.18-34.

78 M. S. Akbar, 'The folly of drone attacks and U.S. strategy', 5 October 2012, http://edition.cnn.com, (accessed 15 November 2017). 


\begin{tabular}{lccc}
\hline Year & $\begin{array}{c}\text { US Drone } \\
\text { Strikes }\end{array}$ & $\begin{array}{c}\text { Minimum } \\
\text { people killed }\end{array}$ & $\begin{array}{c}\text { Minimum } \\
\text { civilians killed }\end{array}$ \\
\hline 2009 & 54 & 471 & 100 \\
2010 & 128 & 755 & 89 \\
2011 & 75 & 362 & 52 \\
2012 & 50 & 212 & 13 \\
2013 & 27 & 109 & 0 \\
2014 & 25 & 115 & 0 \\
2015 & 13 & 60 & 2 \\
2016 & 3 & 11 & 1 \\
2017 & 5 & 15 & 424 \\
Total & 429 & 2514 & \\
\hline
\end{tabular}

Source: The Bureau of Investigative Journalism (TBIJ.com).

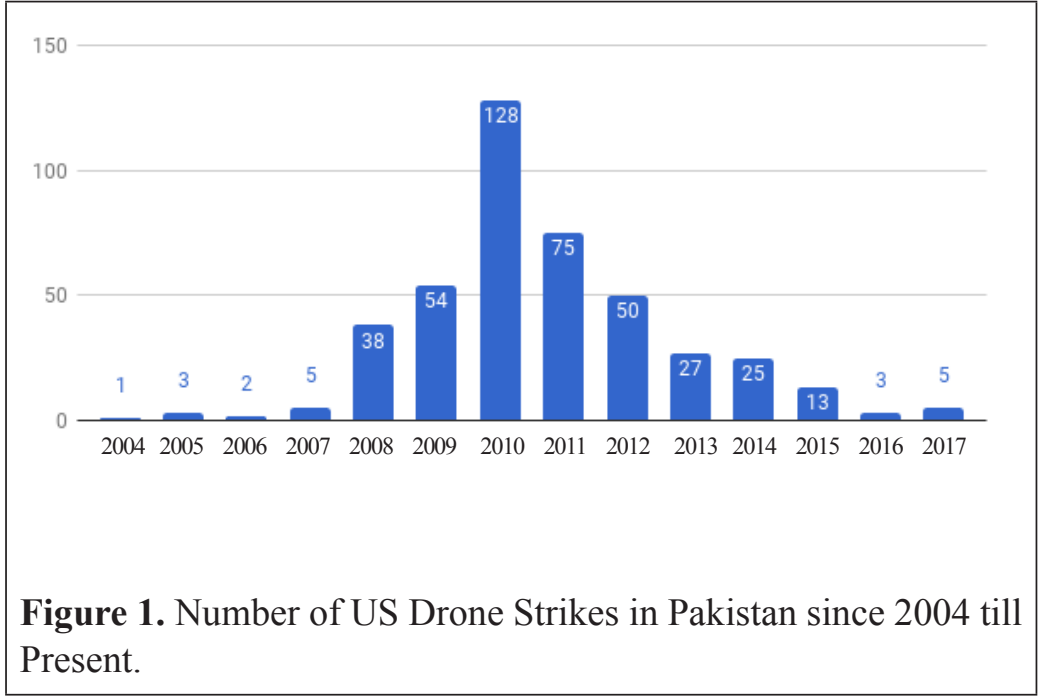

Source: The Bureau of Investigative Journalism (TBIJ.com).

This chart shows that the number of drone strikes was the highest in 2010 showing 128 strikes while after 2010, a gradual decrease is seen because of the strict action taken by Pakistan's army.

On December 9, 2011, Pakistan's Army chief Gen. Ashfaq Parvez Kayani issued a directive to shoot down USA combat drones 
violating Pakistan's air space. Therefore, to appease the Pakistan Army, the USA decreased its drone strike and restricted it to high profile terrorists only. ${ }^{79}$

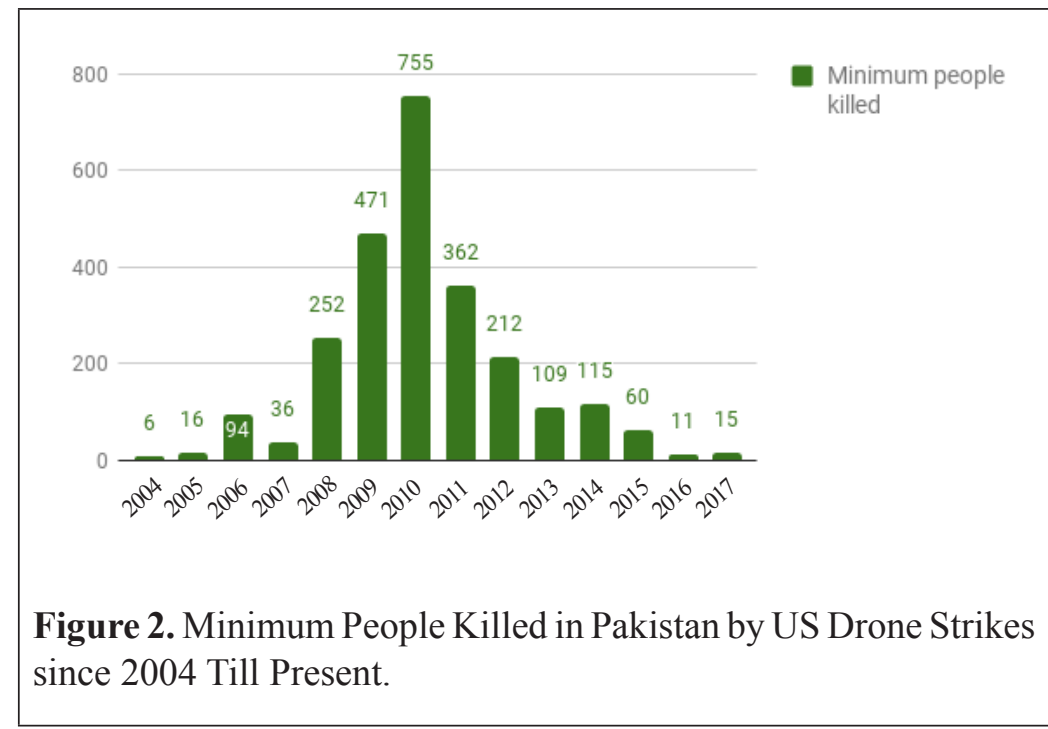

Source: The Bureau of Investigative Journalism (TBIJ.com).

The chart above describes the number of killings per year which shows that in 2004, the number of minimum people killed was 6 . It was the highest in 2010 in which 755 minimum people were killed. After 2010 there was a gradual decrease in the killings as a result of Pakistani administration's strict stance.

79 Mohsin, 'Pakistan says U.S. drones in its air space will be shot down,' 12 December 2011,http://worldnews.msnbc.msn.com/_news/2011/12/10/9352886, (accessed 15 November 2017). 


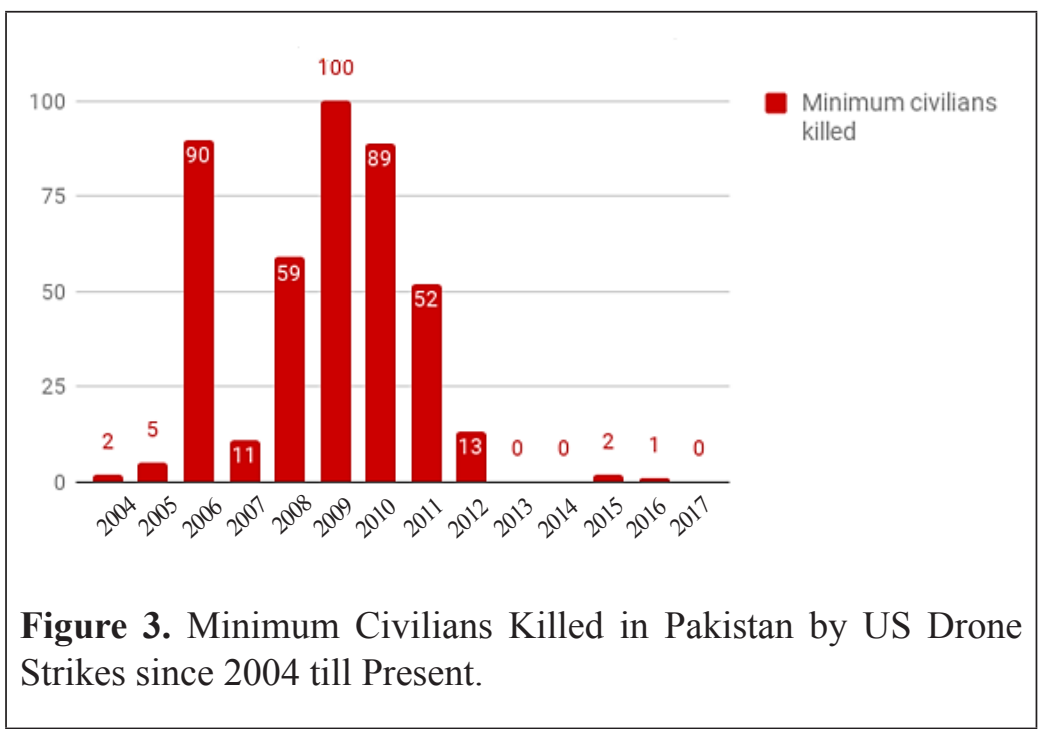

Source: The Bureau of Investigative Journalism (TBIJ.com).

This chart shows the number of civilian killings on a yearly basis which indicates that during 2009, one hundred civilians were killed. In 2006, 90 civilians were killed followed by 2010 in which the US drone strikes killed 89 civilians in Pakistan.

Table 2. Number of Drone Strikes by USA in Pakistan according to Presidency

\section{US President}

$\begin{array}{cc}\begin{array}{c}\text { US Drone } \\ \text { strikes }\end{array} & \begin{array}{c}\text { Minimum } \\ \text { people } \\ \text { killed }\end{array}\end{array}$

George Bush

January 20, 2001 to January 20, 2009

51

$$
410
$$

Barack Hussain Obama

January 20, 2009 to January 20,2017

Donald Trump

January 20, 2017 onwards

Source: The Bureau of Investigative Journalism (TBIJ.com). 


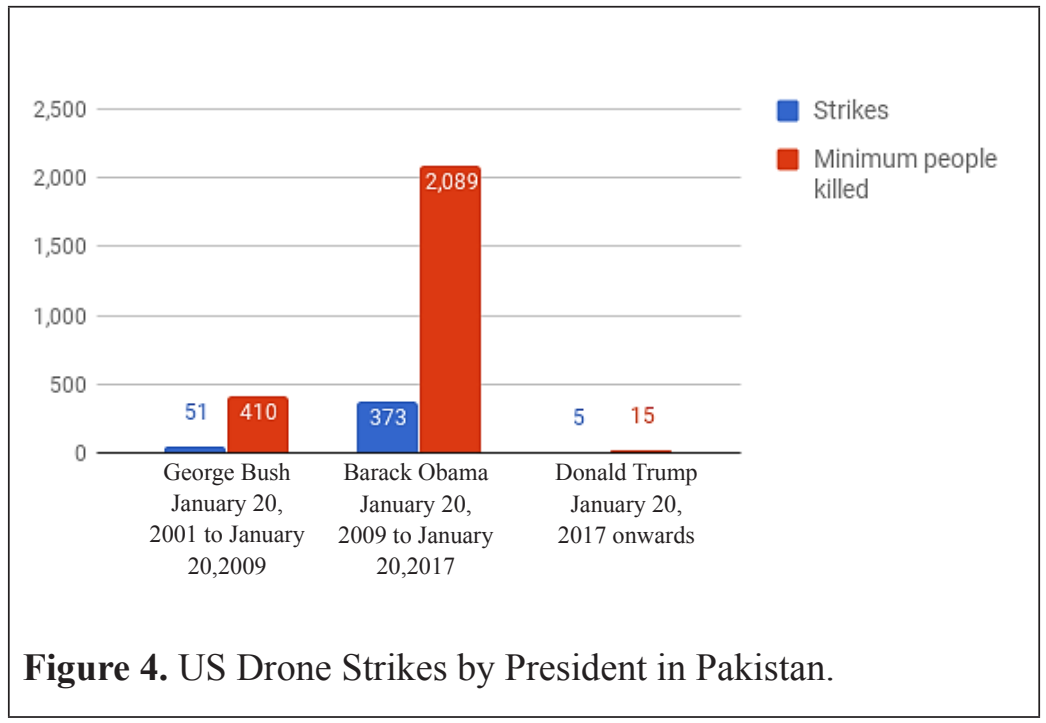

Source: The Bureau of Investigative Journalism (TBIJ.com).

The chart above shows the number of strikes during different presidential eras which demonstrate that during the George W. Bush presidency a minimum of 410 people were killed in 51drone strikes. During the Barack Obama presidency a minimum of 2,089 minimum people were killed while during the Donald Trump presidency from January 2017 onwards a minimum of 15 people were killed in 5 drone strikes.

Table 3. Casualty Rates for Us Drone Strikes since 2004 till the Present in Pakistan (People Killed per Strike)

\begin{tabular}{ccc}
\hline Year & Total casualty rate & Civilian casualty rate \\
\hline 2004 & 6 & 2 \\
2005 & 5.3 & 1.7 \\
2006 & 47 & 45 \\
2007 & 7.2 & 2.2 \\
2008 & 6.6 & 1.6 \\
2009 & 8.7 & 1.9 \\
2010 & 5.9 & 0.7 \\
2011 & 4.8 & 0.7 \\
\hline
\end{tabular}




\begin{tabular}{ccc}
\hline Year & Total casualty rate & Civilian casualty rate \\
\hline 2012 & 4.2 & 0.3 \\
2013 & 4 & 0 \\
2014 & 4.6 & 0 \\
2015 & 4.6 & 0.2 \\
2016 & 3.7 & 0.3 \\
2017 & 3 & 0 \\
\hline
\end{tabular}

Source: The Bureau of Investigative Journalism (TBIJ.com).

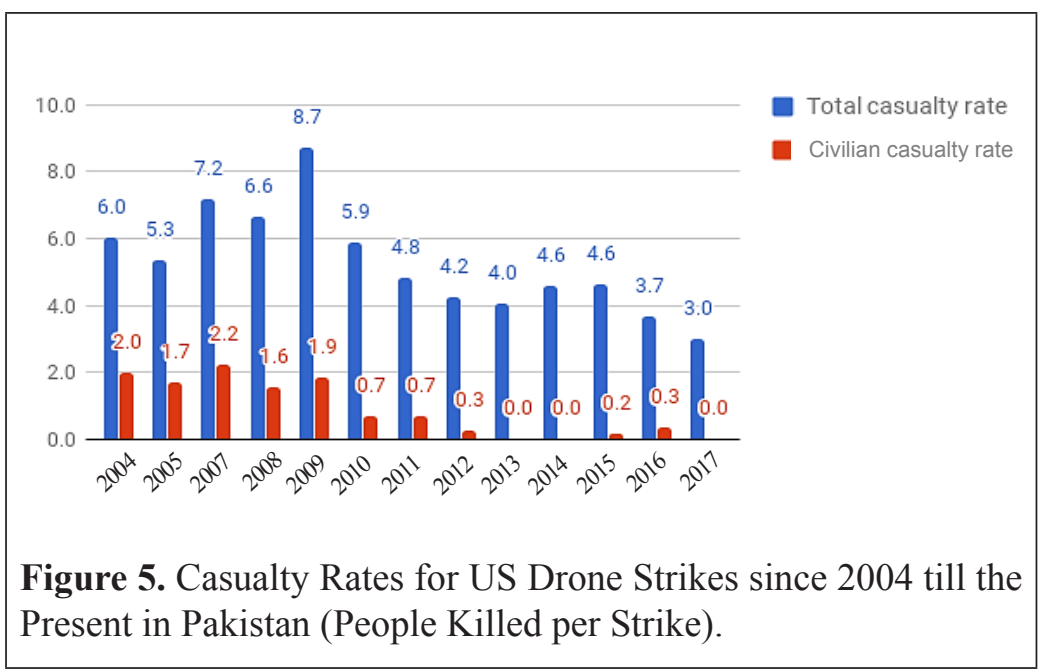

Note: 2006 data has been excluded as an attack in October that year.

Source: The Bureau of Investigative Journalism (TBIJ.com).

The chart above demonstrates total casualty rates and civilian casualty rates from 2004 to 2017. It indicate that the total casualty rate was 7.2 while the civilian casualty rate was 2.2 . In 2009 the total casualty rate was 8.7 while the civilian casualty rate was 1.9 while it was the minimum in 2017 with 3.0 total casualty rates and zero civilian casualty rates.

Hakeem Khan told the Centre for Civilians in Conflict (CIVIC) that he was in pain, and he struggled to move as he lost his leg after a drone missile hit his neighbour's home. Women in the areas frequently struck by drones have inadequate earning resources. Lack of insurance facilities causes widows and orphans to live miserably. 
Sons are supposed to quit their schools to earn, and daughters skip education to look after their families. ${ }^{80}$ In another drone strike in Pakistan, instead of hitting the Taliban, the missile struck the house of a tribal elder and member of the local pro-government peace committee, Malik Gulistan Khan, killing him and four other members of his family ${ }^{81}$ His 18 year-old son Adnan told, "I lost my father, three brothers, and my cousin in this attack." Adnan's uncle Habib Khan said, "We did nothing, had no connection with militants at all. Our family supported the government and in fact... was a member of a local peace committee." The family of the deceased has submitted all the documents related to the deaths of their five family members to the Centre for Civilians in Conflict, along with the report from the Assistant Political Agent of South Waziristan and a local Jirga demanding the government to give them compensation. They are depressed with the passing of their family members. ${ }^{82}$

Amnesty International's report, Will I be next? US drone strikes in Pakistan focuses on nine strikes which resulted in civilian deaths out of the alleged 45 strikes in Pakistan's Waziristan region from January 2012 to August 2013. The report provides the details of the killing of 68 year-old Mamana Bibi by a drone strike while collecting okra in the fields of the Tappi village near Miranshah, North Waziristan on 24 October 2012. One of her granddaughters found her and reported. "I saw her shoes. We found her mutilated body a short time afterwards. It had been thrown quite a long distance away by the blast and it was in pieces." 83

The Amnesty researchers told Pakistani intelligence officials that a local Taliban terrorist used a satellite phone on a road adjacent to

${ }_{80}$ N. Shah., R. Chopra., J. Morna., C. Grut., E. Howie., D. Mule., \& M. Abbott, The civilian impact of drones: Unexamined costs, unanswered questions, Center for Civilians in Conflict, Columbia Law School Human Rights Clinic, 20, 2012.

81 F. Kutty, 'Drone warfare book review: Medea Benjamin, drone warfare killing by remote control (London: Verso 2012)', 11 J. Int'l L. \& Int'l Relations, Valparaiso University Legal Studies Research Paper No. 15-2, 2015.

82 A Rapporteur of Center for Civilians in Conflict, Civilian Harm and Conflict in Northwest Pakistan [website], 2010, www.civiliansinconflict.org, (accessed 15 December 2017).

83 Amnesty International, "Will I be next?" US drone strikes in Pakistan, [website], 2013,https://www.amnestyusa.org, (accessed 15 November 2017). 
Mamana Bibi 10 minutes before the strike. The CIA officials said that they were not aware of the reason for her killing except her presence was close to a Taliban militant. Amnesty International researchers did not find any evidence of the presence of any terrorist in the area at the time of the strike, and the place of the drone strike was nearly 1,000 feet away from the nearest road.

The said Amnesty report also gave details of a group of 18 labourers, including a 14 years old boy killed in a drone strike in July 2012 in Pakistan. A group of men and women had gathered for their evening meal when the first missile struck. The field research by Amnesty International discovered that the strike was then tailed by another missile killing rescuers who were trying to recover bodies. It was the first time that all victims of the drone strike were identified.

Mustafa Qadri, who directed the research, said: "We cannot find any justification for these killings. They are genuine threats to the USA and its allies in the region, and drone strikes may be lawful in some circumstances. But it is hard to believe that a group of labourers, or an elderly woman surrounded by her grandchildren, were endangering anyone at all, let alone posing an imminent threat to the United States."

The report states. "Amnesty International has serious concerns that this attack violates the prohibition of the arbitrary deprivation of life and may constitute war crimes or extrajudicial executions." ${ }^{\circ 4}$

\section{FINANCIAL CRISES, DISPLACEMENT AND DEPRESSION}

Ownership of land is a valuable asset for a family in northern Pakistan where a house is small and accommodates several families. Given such socio-economic conditions, drone strikes on any house produce a great degree of vulnerability and homelessness. The statistics are high, implying increased misery and suffering in the society. Many people are known to have survived by taking shelters in mosques. For instance, Usman Wazir, who despite having a stable economic

84 Amnesty International, USA must be held to account for drone killings in Pakistan, [website], 2013, https://www.amnesty.org, (accessed 15 November 2017). 
background, has become homeless due to a drone strike at his house. That drone strike had taken the life of his brother, spouse and young children. Shakeel Khan, who now looks after his old parents, saved himself from a drone strike, though the strike claimed the lives of other family members. Shakeel Khan has spoken to the Centre for Civilians in Conflict that he is struggling to support himself and his parents. He said, "We don't have enough to reconstruct our houses and fear that the drones will strike us again." 85 Daud Khan and his family were forced to move from their village in Waziristan as they did not have enough money to reconstruct their house wrecked in a drone attack. Daud Khan was at his home with his 10 year-old son Khaliq in Northern Waziristan when a drone missile struck his house. He told that, "The day before a Taliban had come to the house and asked for lunch. I was afraid of them and was unable to stop them because all the local people had to offer them food. They stayed for about one hour and then left. The very next day our house was hit and my only son Khaliq was killed. I saw his body, completely burnt." $" 86$

Psychological distress is a harmful aftereffect of drone attacks which is tough to evaluate and will be an insidious problem for residents for years to come, even after the completion of drone attacks. In the northern areas of Pakistan, civilians are living in fear of being hit by drones flying there 24 hours a day. Michael Kugelman of the Woodrow Wilson International Centre for Scholars said, "I have heard Pakistanis speak about children in the tribal areas who become hysterical when they hear the characteristic buzz of a drone. Imagine the effect this has on psyches, and particularly on young ones already scarred by war and displacement." The scariness or anxiety due to covert drone attacks can greatly affect the whole community according to Kugelman. ${ }^{87}$

${ }_{85}$ N. Shah., R. Chopra., J. Morna., C. Grut., E. Howie., D. Mule., \& M. Abbott, The civilian impact of drones: Unexamined costs, unanswered questions, Center for Civilians in Conflict, Columbia Law School Human Rights Clinic, 20, 2012.

86 The World Can't Wait, 'Photos of Victims of US drone Wars in Pakistan and Yemen', 17 April 2014, https://www.worldcantwait.net, (accessed 24 November 2017).

87 'Youth disrupted: Effects of U.S. drone strikes on children in targeted areas, https://pakistanthinktank.org/children-killed-in-drone-attacks-in-pakistan, (accessed 12 November 2017). 
One victim said to the Centre for Civilians in Conflict, "We fear that the drones will strike us again... my aged parents are often in a state of fear. We are depressed, anxious and constantly remembering our deceased family members... it often compels me to leave this place." Another man expressed the suffering of his sister-in-law whose husband and two sons were killed in a US drone strike in Pakistan, "After their death, she is mentally upset...she is always screaming and shouting at night and demanding me to take her to their graves." 88

Due to the secret striking criteria, civilians living in the drone targeted areas of Pakistan "do not know when, where, or against whom a drone would strike." The obscure nature of the strikes, especially concerning signature strikes, creates a constant fear that a family member will be unexpectedly killed. Moreover, civilians who are victims of drone attacks may be presumed to be associated with terrorists. Victims face the double load of "dealing with a physical attack and a societal stigma". ${ }^{89}$

The lives of civilians in areas where drones regularly operate are like hell on earth. In addition to fear, people who live in the areas where drones constantly operate described signs of "anxiety and post-traumatic stress disorder". Victims also described "emotional breakdowns, running indoors or hiding when drones appear above, fainting, nightmares and other intrusive thoughts, hyper-startled reactions to loud noises, outbursts of anger or irritability and loss of appetite.$^{90}$ According to medical health practitioners of Pakistan, in drone targeted areas insomnia and other physical symptoms are very common. ${ }^{91}$

88 K. Grayson, 'Cultural politics of targeted killing: On drones, counter-insurgency, and violence', Routledge, 2016.

89 S. Holewinski, 'The Constitutional and Counterterrorism Implications of Targeted Killing', 30 April 2013, https://civiliansinconflict.org, (accessed 17 November 2017).

90 M. N. Riaz., R. Sultana., S. Z. Shah., N. Batool., \& M. G. Murad, 'Outcomes of belief in just world among victims of natural and man-made disaster: Moderating role of resilience', Pakistan Journal of Psychological Research, vol. 30 , no. 1,2015 , p. 39.

91 C. Wood, 'Drones causing mass trauma among civilians,' major study finds', 25 September 2012, [website], https://www.thebureauinvestigates.com, (accessed 29 November 2017). 


\section{ARMED DRONES AND THE CONCERNS OF INTERNATIONAL ORGANISATIONS}

International organisations especially the Amnesty International and Human Rights Watch have, through a joint report, raised their serious concerns over the extrajudicial killings of Pakistan's civilians. This report states that the US has violated international laws and therefore "US officials responsible for the secret drone campaign against suspected terrorists in Pakistan may have committed war crimes and should stand trial." ${ }^{22}$ The Human Rights Watch calls upon the US government to explain publicly its legal justification for conducting targeted killings and the legitimate restrictions of drone strikes which were ignored by the US authority. This has further increased concerns about the legality of the US's drone strikes. ${ }^{93}$ Both Human Rights Watch and Amnesty International call upon the US to share the information related to drone strikes publicly including videos of the strikes to show that the strikes comply with international law standards. Arguably, the US should investigate allegations of extrajudicial killings where there is sound evidence of unlawful action by US officials. The US administration should also arrange compensation to all victims of illegitimate strikes and prosecute those CIA officials who are responsible for conducting unlawful strikes. ${ }^{94}$

Fifty other organisations are also demanding:-

- The UN Secretary-General to consider the worries of Navi Pillay who is the United Nation's leading human rights official and investigate whether the drone strikes are violating international laws. Additionally, impose sanctions against the states which are utilising, having and making armed drones.

- The Prosecutor of the International Criminal Court to investigate and conduct a criminal trial of those responsible for the killings of innocent civilians in drone strikes.

92 The Guardian, 'US drone strikes could be classed as war crimes, says Amnesty International', 22 October 2013, https://www.theguardian.com, (accessed 22 November 2017).

93 Human rights watch, 'Q \& A: US Targeted Killings and International Law', 19 December 2011, https://www.hrw.org, (accessed 13 November 2017).

94 Amnesty International, USA must be held to account for drone killings in Pakistan, [website], 2013, https://www.amnesty.org, (accessed 15 November 2017). 
- The US Secretary of State and the US ambassadors in other states to support any international agreement prohibiting the possession or use of armed drones.

- The US to end its "kill list" program. ${ }^{95}$

\section{CONCLUSION}

Drones have desensitised and brutalised war by eliminating soldiers from the battlefield. Drone encounters draw a fine line between legitimate uses of drones and extrajudicial killings. In order to safeguard human rights, states possessing armed drones must update their knowledge about human rights responsibilities under international laws. Also, the use of drones must be strengthened through stringent accountability measures. Drones work as a new approach for calamities in current disputes. Therefore, the use of this disastrous drone force should be eliminated for creating ethical and legal problems. In making war "less human, we may also be making it less humane." ${ }^{96}$ In order to know the legitimacy of drone attacks, it is important to note that article 2(4) of the UN charter prohibits any member state to use force against any other member state of the United Nations. Article 51 is the only exception that allows the use of force under "Customary International Law" in self-defence. Thus, US drone attacks in Pakistan make up an act of war because the use of lethal force is only lawful for self-defence in real armed conflict. According to the ICJ, targeting non-state actors in the "host countries" is a violation of Customary International Law. A foreign state can target terrorist groups with the consent of the "host state". However, drone strikes without the consent or wish of a "host state" are completely unlawful. ${ }^{97}$

Even if drone attacks are legitimate or do not form an act of war against any state or are being performed with the consent of the "host state", they have to meet specified humanitarian law doctrines. In

95 D. Swanson, '50 Organizations Seek Ban on Armed Drones', 2013, 10 November 2013, http://rootsaction.org, (accessed 21 November 2017).

96 P. Hassner, L. Xiang, J. Mazo \& B. Tertrais, 'Politics and international relations', Global Politics and Strategy, vol.52, no.1, 2010, p.199-226.

97 J. Bachman, 'Drones are bringing the warzone to a theater near you', Peace Review, vol. 27, no.4, 2015, p. 418-423. 
the case of Pakistan, the absence of official consent for drone strikes in the territory of Pakistan is a violation of its sovereignty. Even if Pakistan has given secret or tacit consent as claimed by the US, drone strikes must operate based on the principles of distinction, necessity and proportionality. Human rights groups expressed severe concerns that Pakistan's government has failed to safeguard and provide the civil rights assured under articles 15, 16, 20, 24 of the constitution of the Islamic Republic of Pakistan 1973 to the victims of drone attacks. Pakistan must independently investigate all drone strikes in the country and ensure access to justice and compensation for victims. Moreover, we must end the conspiracy of silence against drone strikes and shine the light of the independent investigation into the practice. The drone strikes are not only on the individuals who have been killed but also on international law itself.

\section{REFERENCES}

A Rapporteur of Center for Civilians in Conflict, Civilian Harm and Conflict in Northwest Pakistan [website], 2010, www. civiliansinconflict.org, (accessed 15 December 2017).

A. D. Tutu. (2014). Drones and targeted killing: Legal, moral, and geopolitical issues. Interlink Publishing.

Ahmad Qureshi. W. A. (2017). 'The Legality and Conduct of Drone Attacks', Notre Dame Journal of International \& Comparative Law, 7(2), p.5.

Ahmad, M. I. (2016). The magical realism of body counts: How media credulity and flawed statistics sustain a controversial policy, Journalism, 17(1), p.18-34.

Ahmed, Z. (2015) 'Strengthening standards for consent: The case of U.S. Drone Strikes in Pakistan', Michigan State International Law Review, 23(2), p. 491-500.

Akbar, M. (2015). Drone Attacks and Suicide Bombings: Reflections on Pakistan's Victims, In International Perspectives on Terrorist Victimisation, London, Palgrave Macmillan, pp. 201-224. Available from: E-Book Library.

Akbar, M. S. (2012). The folly of drone attacks and U.S. strategy. Retrieved from http://edition.cnn.com.

Akerson, D. (2014). Applying Jus in Bello Proportionally to Drone Warfare, Or. Rev. International Law, 16, p.173. 
Ali, S., \& Abbott, C. (2013). US Drone Strikes in Pakistan: Ineffective and illegitimate, https://sustainablesecurity.org.

Amnesty International. (2013). "Will I be next?" US drone strikes in Pakistan. Retrieved from https://www.amnestyusa.org.

Amnesty International. (2013). USA must be held to account for drone killings in Pakistan. Retrieved from https://www. amnesty.org.

Anderson, K. (2010). Rise of the drones: Unmanned systems and the future of war, American University Washington College of Law.

AP. (2013). U.N.: Drone strikes violate Pakistan's sovereignty. USA Today. https://www.usatoday.com.

Arasli, J. (2011). States vs. Non-State Actors: Asymmetric Conflict of the 21 st Century and Challenges to Military Transformation, INEGMA Special Report No. 13.

Bachman, J. (2015). Drones are Bringing the Warzone to a Theater Near You, Peace Review, 27(4), p. 418-423.

Barnidge Jr, R. P. (2012). A Qualified Defense of American Drone Attacks in Northwest Pakistan under International Humanitarian Law, BU Int'l LJ, 30, p. 409.

Becker, J., \& Shane, S. (2012). Secret 'kill list' proves a test of Obama's principles and will, New York Times, 29 May 2012, www.nytimes.com/2012/05/29/world/obamas-leadership-inwar-on-al-qaeda.html.

Benjamin, M. (2013). Drone warfare: Killing by remote control, New York and London, Verso Books.

Benjamin, W. (2012). Jeh Johnson, 'National security law, lawyers and lawyering in the Obama Administration, Speech at Yale Law School, http://www.lawfareblog.com/2012/02/jeh-johnsonspeech-at-yale-lawschool.

Bowcott, O. Drone strikes threaten 50 years of international law, says UN rapporteur, The Guardian, 21 June 2012, http:// www.agriculturedefensecoalition.org/sites/default/files/ file/drones_517/517X_1_2012_U.S._Drone_Strikes Threaten_50_Years_of_International_Law_Guardian.co.uk June_21_2012pdf.

Convention on the High Seas Article 23, 29 April 1958, 13 U.S.T. 2312, 450 U.N.T.S. 11

Dworkin,A.(2013). Drones and targeted killing: Defining a European position, European Council on Foreign Relations (ECFR), 35 Old Queen Street, London, SW1H9JA, United Kingdom. 
Entous, A., Gorman, S., \& Perez, E. (2012) US unease over drone strikes: Obama administration charts delicate legal path defending controversial weapons. The Wall Street Journal, 26.

Funk, A. (2016). Drones in contemporary warfare: The implications for human rights, LSE Human Rights Blog.

Grayson, K. (2016). Cultural politics of targeted killing: On drones, counter-insurgency, and violence, Routledge.

Hassner, P. Xiang, L. Mazo, J., \& Tertrais, B., Politics and International Relations Global Politics and Strategy, 52(1), 199-226.

Holewinski, S. (2013). The Constitutional and Counterterrorism Implications of Targeted Killing. Retrieved from 30 April 2013 https://civiliansinconflict.org.

Hosang, J. B. (2017). The effects of paradigm shifts on the rules on the use of force in military operations, Netherlands International Law Review, 64(3), 353-373.

Human rights watch. (2011). Q \& A: US Targeted Killings and International Law, 19 December 2011, https://www.hrw.org.

IT-03-66-T, Prosecutor v. Limaj, 84, 2005, ICTY 30 November 2005.

IT-04-82-T, Prosecutor v. Boskoski, Judgment, 2008, 199-203, ICTY 10 July 2008, Detailing Five Categories of Factors.

Serle, J. (2014). The Lack of Transparency in Drone Attacks, 16 October 2014, http://www.rawa.org.

Jenks, C. (2009). Law from above: Unmanned aerial systems, use of force, and the law of armed conflict', $N D L$, Rev. 85, 649 .

Kelisiana, T. (2009). Targeting the "terrorist enemy": The boundaries of an armed conflict against transnational terrorists, Australian International Law Journal, 16, 161-166 \& See Case No. IT04-82-T, Prosecutor v. Boskoski, Judgment, 2008, 175, ICTY 10 July 2008

Kilcullen, D. (2011) Predator Drones - two words for you - no joke (they provoke counter attacks seen as legitimate defense), Retrieved from https://supportdanielboyd.wordpress.com/ predator-drones-two-words-for-you-no-joke/.

Kim, S. J., Lim, G. J., \& Cho, J. (2017). Drone Relay Stations for Supporting Wireless Communication in Military Operations, In International Conference on Applied Human Factors and Ergonomics, Springer, Cham. 595, 123-130. 
Kleffner, J. K. (2007). From 'belligerents' to 'fighters' and civilians directly participating in hostilities-on the principle of distinction in non-international armed conflicts one hundred years after the second Hague Peace Conference. Netherlands International Law Review, 54(2), 315-336.

Kutty, F., 'Drone Warfare Book Review: Medea Benjamin, Drone Warfare Killing by Remote Control (London: Verso 2012)', 11 J. Int'l L. \& Int'l Relations, Valparaiso University Legal Studies Research Paper No. 15-2, 2015.

Mahapatra, D. A. (2012). Conflict and peace in Eurasia, London and New York: Routledge.

McDonnell, T. M. (2012). Sow What You Reap: Using Predator and Reaper Drones to Carry Out Assassinations or Targeted Killings of Suspected Islamic Terrorists. Geo. Wash. International Law Review, 44, 291.

Mohsin, (2011). Pakistan says U.S. drones in its air space will be shot down. Retrieved from http://worldnews.msnbc.msn. com/_news/2011/12/10/9352886.

Moussa, J. (2010). Can Jus ad Bellum override Jus in Bello? Reaffirming the Separation of the Two Bodies of Law. International Review of the Red Cross, 90, (872), 963-990.

Noam, L. (2010). Extraterritorial use of Force against Non-State Actors, Military Law and the Law of War Review, 49, 173.

O'Connell, M. E. (2010). Unlawful killing with combat drones: A case study of Pakistan, 2004-2009, Notre Dame Law School.

Orr, A. C. (2011). Unmanned, unprecedented, and unresolved: The status of American drone strikes in Pakistan under International Law, Cornell Int'l LJ, 44, 729.

Qureshi, W. A. (2017). The legality and conduct of drone attacks. Notre Dame Journal International Comparative Law, 7(2), 91.

R. P. Barnidge Jr. (2012). A Qualified Defense of American Drone Attacks in Northwest Pakistan under International Humanitarian Law, BU Int'l LJ, 30, 409.

Riaz, M. N., Sultana, R., Shah, S. Z., Batool, N., \& Murad, M. G. (2015). Outcomes of belief in just world among victims of natural and man-made disaster: Moderating role of resilience, Pakistan Journal of Psychological Research, 30(1), 39.

RT America, Drones Kill First, Ask Later. Retrieved from, https:// www.rt.com. 
Sanger, D. E. (2012). Obama order sped up wave of cyber attacks against Iran, The New York Times. Retrieved from http://www. nytimes.com/2012/06/01/world/middleeast/obama-orderedwave-of-cyberattacks-against-iran.html.

Shah, N., Chopra, R., Morna, J., Grut, C., Howie, E., Mule, D., \& Abbott, M. (2012). The civilian impact of drones: Unexamined costs, unanswered questions, Center for Civilians in Conflict, Columbia Law School Human Rights Clinic, 20.

Sperotto, F. (2014). The future of the American Fight against Terrorism, Rivista di Studi Politici Internazionali, 221-230.

Staff, C. W. (2012). Drone strikes kill, maim, and traumatize too many civilians, US Study Says. Retrieved from edition.cnn. com/2012/09/25/world/asia/pakistan-us-drone-strikes.

Sterio, M. (2012).The United States' use of drones in the War on Terror: the (IL) legality of targeted killings under international law', Case W. Res. J. Int'l L., 45, 197.

Strawser, B. J. et al. (2014). Opposing perspectives on the drone debate, (1st edn), Palgrave Macmillan in the United State.

Summers, J. (2011). Kosovo: A Precedent?: The declaration of independence, the advisory opinion and implications for statehood, self-determination and minority rights, Leiden Boston, Brill.

Swanson, D. (2013). 50 Organizations Seek Ban on Armed Drones. Retrieved from http://rootsaction.org.

Tandler, J. (2013). Known and Unknowns: President Obama's Lethal Drone Doctrine. Fondation pour la Recherche Strategique note, 7(13), 1-5.

Tau, B. (2012). Brennan: Drones 'Necessary', POLITICO', POLITICO. Retrieved from https://www.politico.com/ story/2012/04/brennan-drones-necessary-not-vengeance075751.

The Bureau of Investigative Journalism. Retrieved from https:// www.thebureauinvestigates.com.

The Guardian. (2013). US drone strikes could be classed as war crimes, says Amnesty International. Retrieved from https:// www.theguardian.com.

The World Can't Wait. (2014). Photos of Victims of US drone Wars in Pakistan and Yemen. Retrieved from https://www. worldcantwait.net.

Tutu, A. D. (2014). Drones and targeted killing: Legal, moral, and geopolitical issues, Interlink Publishing. 
U.N. (2016). Pakistan presses on its demand for end to illegal drone strikes', THE NEWS. Retrieved from https://www.thenews. com.pk/latest/132367-Pakistan-presses-demand-end-illegaldrone-strikes.

Walsh, D. (2012). Drone war spurs militants to deadly reprisals. New York Times. Retrieved from http://www.nytimes. com/2012/12/30/world/asia/drone-war-in-pakistan-spursmilitants-to-deadly-reprisals.html.

Williams, R. (2014). Current unmanned aircraft state law landscape. National Conference of State Legislatures.

WILPF.(2014). Armed drones killing human rights?. Retrieved from http://wilpf.org.

Wittes, B. (2013). U.N. special rapporteur statement on Pakistan and drone strikes. Retrieved from http://www.lawfareblog.com.

Wood, C. (2012). Drones causing mass trauma among civilians,' major study finds. Retrieved from https://www. thebureauinvestigates.com.

Woods, C. (2012) Pakistan 'Categorically Rejects' Claim That It Tacitly Allows U.S. Drone Strikes. The Bureau of Investigative Journalism. Retrieved from https://www. thebureauinvestigates.com/stories/2012-09-28/pakistancategorically-rejects-claim-that-it-tacitly-allows-us-dronestrikes. 